\title{
Instruments to Assess Physical Activity in Primary Education Students with Autism Spectrum Disorder: A Systematic Review
}

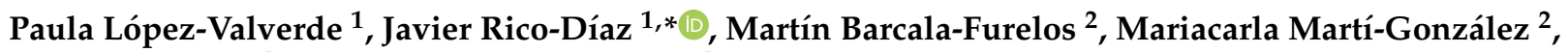 \\ Juan L. Martín ${ }^{2}$ (i) and Sergio López-García ${ }^{3}$ (1) \\ 1 Faculty of Education Sciences, Universidade de Santiago de Compostela, \\ 15782 Santiago de Compostela, Spain; paula262lv@gmail.com \\ 2 Faculty of Health Sciences, European University of the Atlantic, 39011 Santander, Spain; \\ martin.barcala@uneatlantico.es (M.B.-F.); mariacarla.marti@uneatlantico.es (M.M.-G.); \\ juan.martin@uneatlantico.es (J.L.M.) \\ 3 Faculty of Education, Pontifical University of Salamanca, 37007 Salamanca, Spain; slopezga@upsa.es \\ * Correspondence: javier.rico.diaz@usc.es
}

Citation: López-Valverde, P.; Rico-Díaz, J.; Barcala-Furelos, M.; Martí-González, M.; Martín, J.L.; López-García, S. Instruments to Assess Physical Activity in Primary Education Students with Autism Spectrum Disorder: A Systematic Review. Int. J. Environ. Res. Public Health 2021, 18, 4913. https:// doi.org/10.3390/ijerph18094913

Academic Editor:

Rubén Trigueros-Ramos

Received: 21 March 2021

Accepted: 30 April 2021

Published: 5 May 2021

Publisher's Note: MDPI stays neutral with regard to jurisdictional claims in published maps and institutional affiliations.

Copyright: (c) 2021 by the authors. Licensee MDPI, Basel, Switzerland. This article is an open access article distributed under the terms and conditions of the Creative Commons Attribution (CC BY) license (https:// creativecommons.org/licenses/by/ $4.0 /)$

\begin{abstract}
The scientific evidence supports that physical inactivity in childhood is a reality throughout the world which generates important consequences in the global development of children. Young people with Autism Spectrum Disorder (ASD), due to the characteristics of the disorder they suffer, constitute a group at risk. Therefore, assessing the levels of physical activity (PA) in this group is fundamental for subsequent decision making and implementation of PA promotion programmes. Consequently, the aim of this systematic review was to identify, summarise and analyse the main instruments used to assess the levels of PA (in terms of time and/or intensity) in primary school children diagnosed with ASD. Scientific articles in English and Spanish published in five databases were reviewed: PsycINFO, WOS, SPORTDiscus, Scopus and PubMed, following the guidelines of the PRISMA statement. Out of the 605 articles identified, 12 met the previously established inclusion criteria. The instruments used by the studies analysed were divided into two main groups: accelerometers and questionnaires. Both showed different strengths and limitations but agreed on the low levels registered of PA in children with ASD. For this reason, it is considered necessary that further research be carried out in this field, as well as the development and implementation of sports programmes adjusted and adapted to the needs and characteristics of the ASD group.
\end{abstract}

Keywords: autism spectrum disorder; ASD; physical activity; primary school; children; measurement

\section{Introduction}

Physical inactivity is a major risk factor for mortality worldwide and there is a high prevalence at all age levels [1]. Its incidence has increased progressively over the last few years, and it is a determining factor in the emergence of non-communicable diseases, such as cardiovascular diseases, cancer or diabetes [2] and respiratory diseases [3]. Furthermore, it contributes to the increase of obesity $[3,4]$, another major current global problem, which has almost tripled its prevalence in recent decades [5].

Children are one of the main groups at risk, as approximately $80 \%$ of young people do not meet the recommendations of $60 \mathrm{~min}$ of daily moderate-to-high intensity physical activity (PA) [2]. Within this group, young people with Autism Spectrum Disorder (ASD) present an even greater risk of inactivity than their peers with normotypical development, since their particular characteristics, which define the disorder they suffer, limit their own practice of PA [6].

ASD is characterised by difficulties in communication and social interaction and the presence of restricted, repetitive and stereotyped behaviours and interests; motor difficulties and comorbid intellectual disability (ID) are also common [7]. A recent report published by the Centers for Disease Control and Prevention (CDC) estimated that this 
disorder affects 1 in 59 children [8]. These socio-communicative, behavioural and motor impairments $[9,10]$, combined with stereotypical attitudes, may reduce opportunities to participate in physical activity and sport. This contributes to increased sedentariness among young people with ASD [6] and to the emergence of diseases affecting health [9], such as overweight [11]. More specifically, the significant barriers with regard to social and communication skills can restrict activities where collaboration is essential, such as participation in team sports or group games [12]. This situation, combined with the usual deficits in motor development, leads children with ASD to opt for simple, solitary activities [12]; in addition to contributing to a sedentary lifestyle, this has a negative impact on their already limited social skills [10]. Their problems to adapt themselves to the alterations in routine also affect their level of PA practice, as it usually involves complex and novel stimuli [9].

Despite the difficulties of young people with ASD to participate in physical sports activities, PA practice has proved to be tremendously beneficial for this group: it favours the development of their social skills $[13,14]$, especially in the areas of interaction, cooperation and adaptation [14]; it decreases the stereotypical behaviours associated with the disorder [15]; it reduces motor deficits, demonstrating general improvements in basic motor skills [16]; and it increases the performance of executive function, which is generally impaired in students with ASD, notably improvements in working memory and meta-cognition [17].

As a result, the promotion of PA for children with ASD is imperative from an educational point of view, introducing all the necessary measures and adaptations. Thus, it would be intrinsically essential to assess the level of PA practice (in terms of time and intensity of practice) of students in order to identify existing problems and design the necessary intervention strategies within the educational context [18]. Additionally, in order to assess the activity patterns of young people with ASD, it would be advisable to first select an instrument that, adapted to their specific characteristics, correctly records their PA levels. In this way, the aim of this systematic review was to identify, summarise and analyse the main instruments used to assess the levels of PA (in terms of time and/or intensity) in primary school children diagnosed with ASD.

\section{Materials and Methods}

\subsection{Search Strategy}

This systematic review was developed along the lines of the PRISMA statement [19] and five international databases (PsycINFO, WOS-Web Of Science, SPORTDiscus with Full Text, Scopus and PubMed) were used to conduct the literature search dated 16 May 2020. We started with the search on PsycINFO. The other searches followed (Table 1).

Table 1. Search strategy in PsycINFO.

\begin{tabular}{|c|c|}
\hline Category & Keywords \\
\hline Autism Spectrum Disorder & $\begin{array}{l}\text { Ti (ASD OR autism OR autism spectrum disorder) OR Ab (ASD OR autism OR autism } \\
\text { spectrum disorder) }\end{array}$ \\
\hline Physical Activity & $\begin{array}{l}\text { Ti (physical activity OR physical exercise OR physical fitness OR physical condition) OR Ab } \\
\text { (physical activity OR physical exercise OR physical fitness OR physical condition) }\end{array}$ \\
\hline Measurement & $\begin{array}{l}\text { Ti (assess }{ }^{*} \text { OR evaluat }{ }^{*} \text { OR measure } \text { OR test }^{*} \text { OR instrument assess } \\
\text { evaluat }\end{array}$ \\
\hline Population & 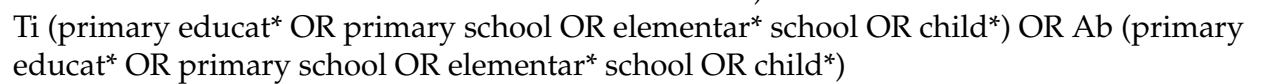 \\
\hline
\end{tabular}

Ti: Title; Ab: Abstract.

The search strategies included four keyword categories (ASD, PA, measurement and population) and two eligibility criteria (language and document type). The different words configuring the theme categories were combined through the Boolean connector OR. Finally, the different categories were mixed through the AND connector. Table 1 shows the 
complete search strategy carried out in PsycINFO, which was subsequently used in the other databases, according to the specific characteristics of each one.

\subsection{Inclusion Criteria}

Once the search in the five databases was completed, the final selection of studies was conducted, according to the previously established inclusion criteria. These were: (1) interventions in the school population (6-12 years old); (2) assessment of the level of PA practice (in terms of time and/or intensity) and (3) the use of objective and/or subjective measurement instruments described in detail. Those articles of which the main objective was not the assessment of PA levels in school populations with ASD, but in which this assessment had to be performed (according to the inclusion criteria already described) in order to achieve the main goal of this study, were also included. In addition, a filter was established by language, selecting only those publications in Spanish or English. No filter was used with respect to the date of publication or completion of the study. Comments, correspondence, opinion articles, abstracts and letters to the editor were also excluded.

\section{Results}

\subsection{Summary of the Studies Included}

The initial search identified 727 articles. Out of these, 122 were duplicates; thus, the titles and abstracts of 605 papers were analysed using the inclusion/exclusion criteria. This left 26 articles to be fully read, concluding the inclusion process with 12 articles (Figure 1).

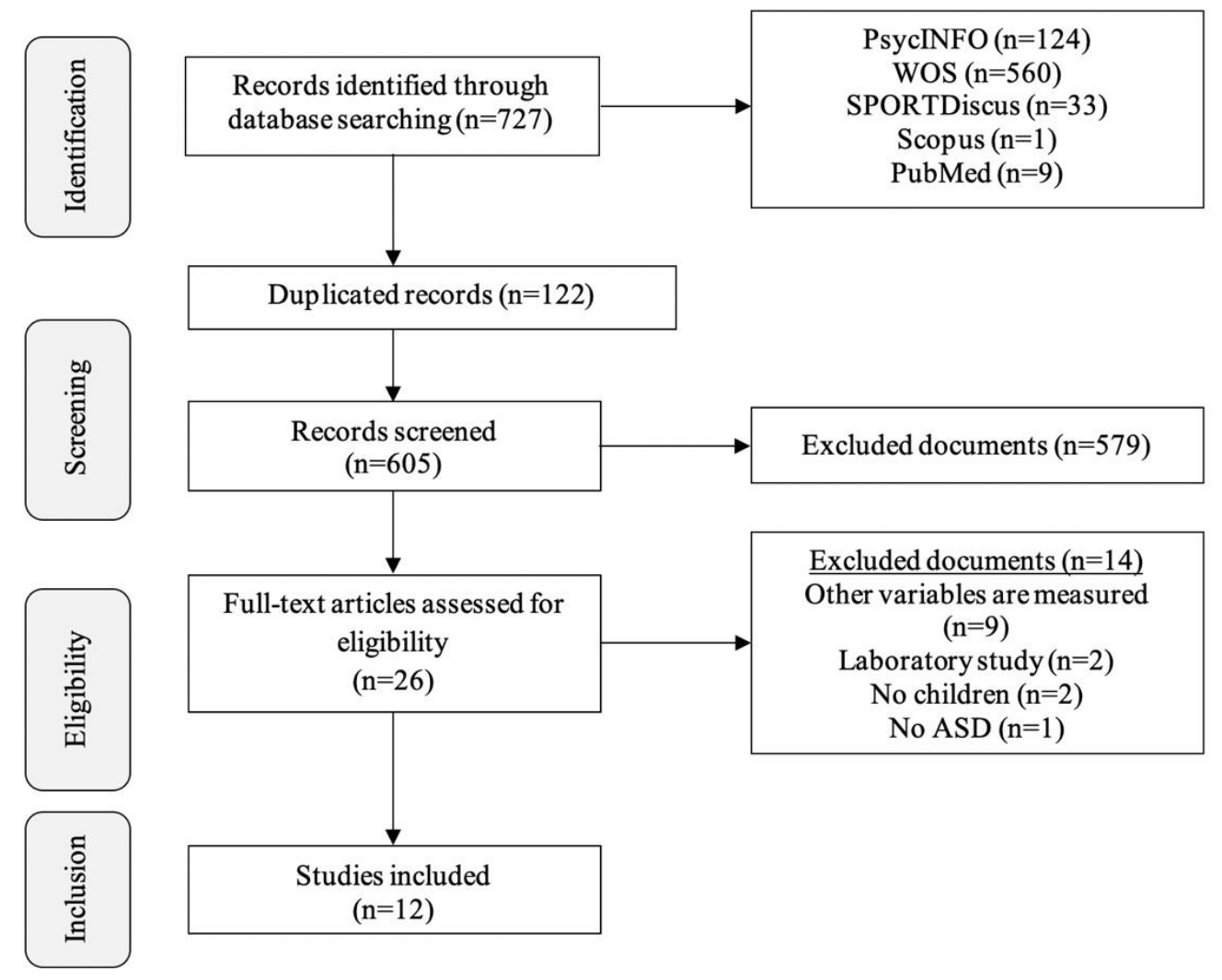

Figure 1. Article selection flowchart.

Tables 2-4 show, in chronological order, a summary of the most outstanding aspects of the 12 studies which met the inclusion criteria. All of them are journal articles published between 2008 and 2019 assessing the level of PA (time and/or intensity) in children with ASD through objective and/or subjective measurement instruments. In total, $50 \%$ of the papers were conducted in the United States. 
Table 2. Cont.

\begin{tabular}{|c|c|c|c|c|c|}
\hline \multirow{2}{*}{$\begin{array}{c}\text { First Author } \\
\text { and Year }\end{array}$} & \multirow{2}{*}{ Country } & \multicolumn{2}{|c|}{ Participants } & \multirow{2}{*}{ Design, Intervention } & \multirow{2}{*}{ Objective } \\
\hline & & Sample & ASD Diagnosis & & \\
\hline $\begin{array}{c}\text { Bricout et al., } \\
2018 \text { [27] }\end{array}$ & France & $\begin{array}{l}40 \text { schoolchildren (all } \\
\text { children): ASD (20) and } \\
\text { Non-ASD (20) between } \\
8 \text { and } 13 \text { years old. }\end{array}$ & $\begin{array}{l}\text { High-functioning autism } \\
(C I>70) \text { without } \\
\text { concomitant ID. } \\
\text { Exclusion criteria: } \\
\text { Contraindication for } \\
\text { physical exercise, } \\
\text { psychiatric or medical } \\
\text { disorders, respiratory } \\
\text { disorders and medical } \\
\text { treatment. } \\
\text { Manifest comorbidities: } \\
\text { no. }\end{array}$ & $\begin{array}{l}\text { Laboratory environment } \\
\text { (respiratory capacity and } \\
\text { physical fitness) and } \\
\text { natural environment of } \\
\text { students in order to } \\
\text { measure PA (7 days). }\end{array}$ & $\begin{array}{l}\text { To examine the } \\
\text { cardiorespiratory fitness } \\
\text { of children with ASD and } \\
\text { compare it with that of } \\
\text { normotypically } \\
\text { developing } \\
\text { schoolchildren. }\end{array}$ \\
\hline $\begin{array}{l}\text { Healy et al., } \\
2018 \text { [28] }\end{array}$ & Ireland & $\begin{array}{l}110 \text { schoolchildren: ASD } \\
\text { (55) and Non-ASD }(55) \\
\text { aged } 9 . \text { Girls represented } \\
15 \%(n=8) \text { of } \\
\text { both groups. }\end{array}$ & $\begin{array}{l}\text { Formal diagnosis of ASD. } \\
\text { The degree of severity } \\
\text { was not } \\
\text { specified.Manifest } \\
\text { comorbidities: no. }\end{array}$ & $\begin{array}{l}\text { Data from a nationally } \\
\text { representative cohort study. }\end{array}$ & $\begin{array}{l}\text { To compare the } \\
\text { psychosocial factors } \\
\text { associated with ASD and } \\
\text { screen time between } \\
\text { children with and } \\
\text { without ASD. }\end{array}$ \\
\hline $\begin{array}{l}\text { Woodman } \\
\text { et al., 2018 } \\
\text { [29] }\end{array}$ & USA & $\begin{array}{l}13 \text { schoolchildren with } \\
\text { ASD ( } 11 \text { boys and } 2 \text { girls) } \\
\text { between } 5 \text { and } 13 \text { years } \\
\text { old (public school for } \\
\text { students with ASD). }\end{array}$ & $\begin{array}{l}\text { Formal diagnosis of ASD, } \\
\text { with concomitant } \\
\text { diagnosis of ID. } \\
\text { Manifest comorbidities: } \\
\text { no. }\end{array}$ & $\begin{array}{l}\text { Jogging programme during } \\
6 \text { consecutive school days. } \\
\text { The intensity of PA was } \\
\text { analysed in a structured } \\
\text { (from 9:50 to 10:25) and } \\
\text { unstructured (from 10:25 to } \\
\text { 10:45) jogging period, } \\
\text { subject to different } \\
\text { musical conditions. }\end{array}$ & $\begin{array}{l}\text { To examine the influence } \\
\text { of music on exercise } \\
\text { intensity in children with } \\
\text { ASD by means of a } \\
\text { jogging programme. }\end{array}$ \\
\hline $\begin{array}{c}\text { Garcia et al., } \\
2019 \text { [30] }\end{array}$ & USA & $\begin{array}{l}14 \text { schoolchildren with } \\
\text { ASD ( } 12 \text { boys and } 2 \text { girls) } \\
\text { aged } 8 \text { to } 17 \text { years old. } \\
\text { Exclusion criteria: serious } \\
\text { physical limitations and } \\
\text { violent behaviour. }\end{array}$ & $\begin{array}{l}\text { Formal diagnosis of ASD. } \\
\text { The degree of severity } \\
\text { was not specified. } \\
\text { Manifest comorbidities: } \\
\text { yes. }\end{array}$ & $\begin{array}{l}\text { 8-week Judo Programme to } \\
\text { promote PA (summer; } \\
1 \text { session of } 45 \text { min per } \\
\text { week). }\end{array}$ & $\begin{array}{l}\text { To examine the } \\
\text { effectiveness of a judo } \\
\text { programme aimed at } \\
\text { promoting } \\
\text { moderate-to-high } \\
\text { intensity PA and } \\
\text { reducing sedentary } \\
\text { behaviours in children } \\
\text { with ASD. }\end{array}$ \\
\hline $\begin{array}{l}\text { Garcia et al., } \\
2019 \text { [31] }\end{array}$ & USA & $\begin{array}{l}49 \text { ASD schoolchildren } \\
\text { ( } 36 \text { boys and } 13 \text { girls) } \\
\text { aged } 8 \text { to } 17 \text { (public } \\
\text { school for ASD students). } \\
\text { Exclusion of } 1 \text { student } \\
\text { (non-compliance } \\
\text { with accelerometer } \\
\text { time criteria). }\end{array}$ & $\begin{array}{l}\text { High-functioning autism } \\
(\mathrm{IQ}>70) \text {. } \\
\text { Manifest comorbidities: } \\
\text { no. }\end{array}$ & $\begin{array}{l}\text { Follow-up during } 1 \text { week ( } 7 \\
\text { days and } 7 \text { nights) to } \\
\text { analyse the quality and } \\
\text { duration of sleep and } \\
\text { regular levels of PA. }\end{array}$ & $\begin{array}{l}\text { To compare demographic } \\
\text { and lifestyle factors with } \\
\text { duration and quality of } \\
\text { sleep in children } \\
\text { with ASD. }\end{array}$ \\
\hline
\end{tabular}

The total sample analysed included 606 participants. Among them, 421 were schoolchildren with ASD: 316 were boys and 105 were girls. From the remaining 185 participants, 169 were children with normotypical development, 10 showed ASD and 6 had visual impairment (VI). Young people with normotypical development made up the control groups in five of the studies $[20,23,25,27,28]$; the remaining papers (seven) did not include a control group. As for the diagnosis of ASD, reported in Table 2, six studies did not specify the degree of severity of the disorder $[22,23,25,26,28,30]$, one included only participants with associated ID [29] and five limited the sample to children with high-functioning autism (IQ $\geq 70$ ) $[20,21,24,27,31]$. Females accounted for $25 \%$ of the total sample, while the age of schoolchildren ranged from 3 to 20 years old.

The results of most studies concluded that children with ASD did not meet the recommendations of daily PA and that, when compared to young people with normotypical development, they were less physically active. On top of that, a high percentage of studies held that girls participated in less PA than boys and that the older the child, the more likely they were to be inactive (Table 4). These data were collected through different PA 
measurement instruments (Table 3). Specifically, the instruments used in the different studies of the review were grouped into two categories; seven articles made use of objective assessment instruments $[20,21,23,26,29,31]$, four used subjective methods $[22,24,25,28]$ and one combined both [27].

Table 3. Measurement instruments of the studies.

\begin{tabular}{|c|c|c|c|c|c|}
\hline \multirow{3}{*}{$\begin{array}{l}\text { First Author } \\
\text { and Year }\end{array}$} & \multicolumn{5}{|c|}{ Measurement Instruments } \\
\hline & \multicolumn{2}{|c|}{ Main Instruments } & \multirow{2}{*}{$\begin{array}{l}\text { Complementary } \\
\text { Instruments }\end{array}$} & \multirow{2}{*}{$\begin{array}{c}\text { Other } \\
\text { Instruments }\end{array}$} & \multirow{2}{*}{ Description } \\
\hline & Objective & Subjective & & & \\
\hline
\end{tabular}

Objective instrument:

Pan, 2008

[20]

$x$

$\mathrm{x}$

(a)

GT1M ActiGraph (uniaxial accelerometer) programmed to collect data at 1-min intervals; tied on the right side of the hip (using an elastic belt). Its use was discontinued at the end of the school day; the data were downloaded immediately and it was restarted the following day.

Objective instrument:

GT3X ActiGraph (triaxial accelerometer) programmed to collect data at 1-min intervals; tied on the right side of the hip (using an elastic belt).

Memari et al., Complementary instruments:

2012 [21]

A logbook/log sheet (families and teachers) to record the hours when the device was not used.

Questionnaire (families) to measure sedentary behaviour.

Subjective instrument:

PA questionnaire (MEND) completed by the families. Selection of 2 out of the 4 questions on the MEND: time dedicated to

Hinckson et al., 2013

[22] activity/inactivity and time dedicated to moderate-to-high intensity PA.

Other instruments:

Nutrition questionnaire (14 items) on the frequency of having breakfast, carbonated drinks, white bread, wholemeal cereals, pastries and fresh food.

6-min walk test (6MWT) to assess physical fitness.

\section{Objective instrument:}

GTX3 + ActiGraph (triaxial accelerometer, valid for children with ID) tied on the right side of the hip (using an elastic belt). It was used at all times (except under the water and at night). The data collected were reduced to 4 categories (sedentary, low, moderate and moderate-to-high intensity).

Complementary instruments:

A logbook/log sheet (families) to record the hours when the device was not used.

Other instruments:

Fitness tests on aerobic capacity, muscle strength and flexibility.

Subjective instrument:

PA questionnaire (adapted from GLTEQ) completed by families and teachers Two key topics: intensity and frequency of PA.

Complementary instruments:

List of barriers (families) against the practice of PA in leisure time.

Daily activity journal (families) to know the type of game (individual or social).

Subjective instrument:

PA questionnaire (CHAMPS) completed by families in order to determine participation in structured and unstructured physical activities (type of activity and frequency).

Complementary instruments:

Screen time questionnaire (families) to determine the number of hours schoolchildren spent sitting or lying down (TV, video games, computer).

Questionnaire on barriers (families) against PA practice (of the person, the family, social, community). 
Table 3. Cont.

\begin{tabular}{|c|c|c|c|c|}
\hline \multirow{3}{*}{$\begin{array}{l}\text { First Author } \\
\text { and Year }\end{array}$} & \multicolumn{4}{|c|}{ Measurement Instruments } \\
\hline & Main Instruments & \multirow{2}{*}{$\begin{array}{l}\text { Complementary } \\
\text { Instruments }\end{array}$} & \multirow{2}{*}{$\begin{array}{c}\text { Other } \\
\text { Instruments }\end{array}$} & \multirow{2}{*}{ Description } \\
\hline & Subjective & & & \\
\hline
\end{tabular}

Objective instrument:

GT3X ActiGraph (triaxial accelerometer) that counts the accelerations at a sampling frequency of $30 \mathrm{HZ}$, tied on the right

Haegele et al., 2018

[26] side of the hip (using an elastic belt). It was used only during the waking state hours and the data were classified into 4 categories (sedentary, low, moderate and high intensity).

Other instruments:

Fitness test (based on the Brockport test) to measure aerobic resistance, upper body muscle strength, abdominal muscle strength and flexibility.

Objective instrument:

Pro-3 SenseWear (triaxial accelerometer) placed on the triceps with an elastic belt to measure PA. It was used $24 \mathrm{~h}$ a day (except when showering or swimming).

Subjective instrument:

PA Questionnaire (PAQ-C) completed by families and

Bricout et al., 2018 [27] $x$

$\mathrm{x}$
Healy et al., 2018 [28]

Woodman

et al., 2018

[29]

Garcia et al., 2019 [30]

Garcia et al. 2019 [31] schoolchildren (9 items). PA periods: week-weekend; with or without a teacher.

Complementary instruments:

A logbook/log sheet (families) to record the hours when the device was not used.

Other instruments:

EUROFIT battery to measure physical fitness.

Subjective instrument:

PA questionnaire (GLTEQ) completed by families (based on the last 14 days; frequency, moderate-to-high or low intensity) and by students (based on the last 7 days; PA practice).

Complementary instruments:

Screen time questionnaire (families) with 3 variables (TV, computers and video games).

Objective instrument:

Omron activity device (Model HJA-750C; triaxial accelerometer) to measure METs (metabolic equivalent of task) and the percentage of 10-s intervals in high-intensity activity. It was placed on the back of the elastic waistband of school uniforms (so that when swinging the arms did not touch the accelerometer). It was used for 6 days (from 09:15 to 10:45).

Objective instrument:

GT9X ActiGraph (triaxial accelerometer which filters out high-frequency vibrations in order to artificially increase the data) programmed to collect data at 1-min intervals; placed on the non-dominant wrist (7 days). Data collected on the initial day were excluded from the analysis (possible artificial increase in PA).

Objective instrument:

GT9X ActiGraph (triaxial accelerometer) placed on the non-dominant wrist. It was used on a 24-h basis (except during water activities) to measure the quality and duration of sleep and the levels of PA.

Complementary instruments:

Screen time questionnaire (families) to determine the number of hours schoolchildren spent in sedentary activities (TV, computers, video games; 7-point scale). 
Table 4. Main results of the studies.

\begin{tabular}{|c|c|c|c|}
\hline $\begin{array}{l}\text { First Author } \\
\text { and Year }\end{array}$ & Results & Limitations & Conclusions \\
\hline Pan, 2008 [20] & $\begin{array}{l}\text { PA is stable, no group was moderately } \\
\text { active for more than } 50 \% \text { of the break time. } \\
\text { Schoolchildren without ID spent more } \\
\text { time in moderate-to-high intensity PA } \\
\text { when compared to students with ASD } \\
\text { ( } 36.15 \% \text { vs. } 27.2 \%) \text {. } \\
\text { Subgroup ASD/Early primary (1st, 2nd } \\
\text { and 3rd) more active than the group } \\
\text { ASD/Late primary (4th, } 5 \text { th and } 6 \text { th). }\end{array}$ & $\begin{array}{l}\text { Cross-sectional design of the studio. } \\
\text { Reduced sample size. } \\
\text { Presence of the accelerometer (possible } \\
\text { rejection by the students). } \\
\text { Data collection in 1-min intervals (possible } \\
\text { underestimation of PA in free play). } \\
\text { Absence of social, behavioural, cognitive } \\
\text { and motor skills assessment (possible } \\
\text { biases in the findings). }\end{array}$ & $\begin{array}{l}\text { The lower level of PA in schoolchildren } \\
\text { with ASD during breaks suggests that } \\
\text { unstructured time during the school day } \\
\text { may need to be redesigned for } \\
\text { structuring. In order to improve the PA } \\
\text { of students with ASD during the breaks, } \\
\text { several types of strategies or } \\
\text { interventions should be developed. }\end{array}$ \\
\hline $\begin{array}{l}\text { Memari et al., } \\
2012 \text { [21] }\end{array}$ & $\begin{array}{l}\text { Significant differences between age } \\
\text { groups and sex for PA (minimum level } \\
\text { of PA among 13-14-year-olds and girls). } \\
\text { More PA in out-of-school hours than } \\
\text { during school } \\
\text { No significant changes were found in PA } \\
\text { levels comparing weekdays } \\
\text { and weekends. }\end{array}$ & $\begin{array}{l}\text { Cross-sectional design of the studio. } \\
\text { Absence of a control group with which to } \\
\text { compare the results. } \\
\text { Homogeneity of the sample (difficulty to } \\
\text { generalise the results to the ASD variety). } \\
\text { Possible biases in the accelerometer } \\
\text { results due to their incompatibility with } \\
\text { aquatic activities and to the presence of } \\
\text { stereotyped behaviours in } \\
\text { schoolchildren with ASD. }\end{array}$ & $\begin{array}{l}\text { The lower level of PA in schoolchildren } \\
\text { with ASD during the school day underlines } \\
\text { the need to revise school programmes for } \\
\text { adapted PA. For a higher level of PA in } \\
\text { children with ASD, they should be given } \\
\text { PA opportunities according to their } \\
\text { socio-demographic profile. }\end{array}$ \\
\hline $\begin{array}{l}\text { Hinckson et al., } \\
2013 \text { [22] }\end{array}$ & $\begin{array}{l}\text { Unclear data, with trivial effects. } \\
\text { Children more active after the } \\
\text { implementation of the programme. }\end{array}$ & $\begin{array}{l}\text { Reduced sample size. } \\
\text { No control group with which to } \\
\text { compare the results. } \\
\text { Non-validated PA questionnaire for } \\
\text { schoolchildren with ID. } \\
\text { Winter and summer assessments (possible } \\
\text { influence of the climate on PA levels). } \\
\text { Absence of quantitative measurements. }\end{array}$ & $\begin{array}{l}\text { A programme specifically designed for } \\
\text { the needs of schoolchildren with ID and } \\
\text { their families is needed. The programme } \\
\text { should focus on healthy living rather } \\
\text { than on managing overweight. The } \\
\text { school may be the appropriate place to } \\
\text { deliver such a programme. Appropriate } \\
\text { tools need to be developed to accurately } \\
\text { determine PA in young people with ID. }\end{array}$ \\
\hline $\begin{array}{l}\text { Tyler et al., } \\
2014 \text { [23] }\end{array}$ & $\begin{array}{l}\text { Children with ASD are less physically } \\
\text { active than their normotypically } \\
\text { developing peers (less time in } \\
\text { moderate-to-high intensity PA and } \\
\text { higher rates of sedentary behaviour). }\end{array}$ & $\begin{array}{l}\text { Uneven sample sizes and } \\
\text { unmatched controls. } \\
\text { Reduced sample size. } \\
\text { Introduction of individual adaptations } \\
\text { in the evaluations. }\end{array}$ & $\begin{array}{l}\text { Children with ASD face well-known } \\
\text { health disparities, so efforts to promote } \\
\text { PA in schools, and through public health } \\
\text { initiatives, must include this group. }\end{array}$ \\
\hline
\end{tabular}

Only 10 (12\%) schoolchildren were physically active. Only $6 \%$ "often" participated in PA, whereas the majority, $85.5 \%$, opted for the

Memari et al., "never/rarely" response.

2015 [24] Boys were more active than girls and the older they were, the more inactive they became.

Preference for playing alone.

Cross-sectional design of the studio. Absence of a control group with which to compare the results. Measures based only on information from families or teachers (possible biases due to subjectivity).

More barriers against PA in schoolchildren with ASD. The total Must et al., number of barriers was inversely 2015 [25] correlated with the number of hours and types of PA, but was directly related to total screen time.
Homogeneous sample (predominantly white and well educated). Exclusive use of qualitative assessment tests (possible subjectivity bias).
Reduced sample size.

The severity of ASD and associated comorbidities were not recorded, so the presence of additional limitations which could influence PA is unknown.

Biases may appear in accelerometer results as they do not record upper body PA. Intervention in a school with many opportunities for PA practice (possible overestimation of results and difficulty to generalise findings).
Only a small percentage of children with ASD are physically active, and the financial concerns, lack of opportunities and socio-demographic factors are major constraints on their ASD.
PA programmes designed to meet the special requirements of the ASD population and conducted by adults with specialised training are urgently needed. Systematic assessment of such programmes will contribute to the development of best practices regarding PA programming for children with ASD.

This study identifies a substantial need for health promotion among young people with ASD and visual impairment, and the results show the need to encourage intervention programmes to help improve these health-related variables. moderate-high intensity PA.
The ASD/VI group was significantly less active than the VI group. 
Table 4. Cont.

\begin{tabular}{|c|c|c|c|}
\hline $\begin{array}{l}\text { First Author } \\
\text { and Year }\end{array}$ & Results & Limitations & Conclusions \\
\hline $\begin{array}{l}\text { Bricout et al., } \\
2018 \text { [27] }\end{array}$ & $\begin{array}{l}\text { The control group was more physically } \\
\text { active than the ASD group (not } \\
\text { significant results in any of the tests: } \\
\text { accelerometer and questionnaire). }\end{array}$ & $\begin{array}{l}\text { Reduced sample size. } \\
\text { Very specific ASD group }(\mathrm{CI}>70) \text { and } \\
\text { absence of girls in the study (difficulty } \\
\text { to generalise results). }\end{array}$ & $\begin{array}{l}\text { The results of the study suggest that } \\
\text { children with ASD are in worse physical } \\
\text { condition than their peers without ASD. } \\
\text { Furthermore, since poor physical } \\
\text { condition is a reliable indicator of poor } \\
\text { health outcomes, this study provides an } \\
\text { important argument for the systematic } \\
\text { implementation of PA programmes } \\
\text { aimed at young people with ASD. }\end{array}$ \\
\hline $\begin{array}{l}\text { Healy et al., } \\
2018 \text { [28] }\end{array}$ & $\begin{array}{l}\text { The ASD group is less physically active } \\
\text { and less involved in sports than the } \\
\text { control group. } \\
\text { Boys (both groups) are significantly } \\
\text { more active and more involved } \\
\text { in sports. }\end{array}$ & $\begin{array}{l}\text { The severity of ASD was not recorded } \\
\text { (difficulty to generalise results). } \\
\text { Exclusive use of qualitative measures } \\
\text { (possible biases due to subjectivity). }\end{array}$ & $\begin{array}{l}\text { The association between negative social } \\
\text { interactions and lower levels of PA in } \\
\text { children with ASD should be examined } \\
\text { as well as the social interventions } \\
\text { developed among schoolchildren with } \\
\text { ASD and their peers in PA settings. }\end{array}$ \\
\hline $\begin{array}{l}\text { Woodman } \\
\text { et al., } 2018 \text { [29] }\end{array}$ & $\begin{array}{l}\text { Average time spent on intense PA of } \\
16 \text { min/day. } \\
\text { More PA levels in the structured period. } \\
\text { In general, slower music produced } \\
\text { greater PA benefits. The exception was } \\
\text { found in schoolchildren with fewer } \\
\text { maladaptive behaviours and mild or } \\
\text { moderate symptoms of autism, who } \\
\text { were more motivated by fast music. }\end{array}$ & $\begin{array}{l}\text { Reduced sample size. } \\
\text { Homogeneity of the sample (difficulty } \\
\text { to generalise the results to the ASD } \\
\text { variety).Unusual daily exercise in the } \\
\text { school (possible overestimation } \\
\text { of results). } \\
\text { Schoolchildren did not participate in the } \\
\text { selection of songs (children with ASD } \\
\text { may be particularly sensitive to music). }\end{array}$ & $\begin{array}{l}\text { Based on the results of the study, music } \\
\text { should be incorporated into physical } \\
\text { education programmes for } \\
\text { schoolchildren with ASD, as it can } \\
\text { motivate this group to participate in PA } \\
\text { in order to prevent obesity and other } \\
\text { health problems. Additionally, jogging } \\
\text { is a low-cost, low-risk intervention } \\
\text { which can be easily implemented in an } \\
\text { educational setting. }\end{array}$ \\
\hline $\begin{array}{c}\text { Garcia et al., } \\
2019 \text { [30] }\end{array}$ & $\begin{array}{l}\text { The daily time spent in } \\
\text { moderate-to-high intensity PA increased } \\
\text { significantly after the judo session. After } \\
\text { the programme, the number of } \\
\text { participants who complied with the } \\
\text { recommendations of } 60 \text { min of daily PA } \\
\text { was increased from } 4 \text { to } 8 \text { and sedentary } \\
\text { behaviours were reduced. }\end{array}$ & $\begin{array}{l}\text { Reduced sample size. } \\
\text { Short duration of the intervention } \\
\text { ( } 8 \text { weeks). } \\
\text { Absence of a control condition (Judo } \\
\text { condition was not compared to an } \\
\text { inactive condition or to a general } \\
\text { exercise class). }\end{array}$ & $\begin{array}{l}\text { The study proved the preliminary } \\
\text { effectiveness of the judo programme to } \\
\text { promote PA among young people with } \\
\text { ASD, finding that } 50 \% \text { of the sample } \\
\text { continued to participate in judo or a } \\
\text { similar martial arts training after the } \\
\text { programme. Further studies are needed } \\
\text { to support these findings, but judo } \\
\text { programmes could be well received by } \\
\text { this group. }\end{array}$ \\
\hline $\begin{array}{c}\text { Garcia et al., } \\
2019 \text { [31] }\end{array}$ & $\begin{array}{l}\text { Children who met the criteria of } \\
\text { duration and quality of sleep had more } \\
\text { minutes of moderate-to-high intensity } \\
\text { PA and less time in sedentary } \\
\text { activities.Only } 15 \% \text { of the sample met } \\
\text { the sleep criteria. }\end{array}$ & $\begin{array}{l}\text { Cross-sectional design of the studio. } \\
\text { Very specific group of ASD (IQ > 70) } \\
\text { (difficulty to generalise results). } \\
\text { The stereotyped behaviours of } \\
\text { schoolchildren with ASD could } \\
\text { artificially increase the data collected by } \\
\text { the accelerometer. }\end{array}$ & $\begin{array}{l}\text { The results of the study showed the } \\
\text { association of healthy lifestyle factors } \\
\text { (HF) with longer sleep among young } \\
\text { people with ASD. } \\
\text { Participants' compliance with the } \\
\text { accelerometer protocol was high (only } \\
\text { one participant did not meet the criteria } \\
\text { for minimum time of use), suggesting } \\
\text { that this method of objectively assessing } \\
\text { ASD may be feasible in the } \\
\text { ASD population. }\end{array}$ \\
\hline
\end{tabular}

\subsection{Objective Measurement Instruments}

The accelerometer, as shown in Table 3, was the common factor in all objective measurements. Only Pan's study [20] made use of the uniaxial accelerometer, while all others used triaxial devices. The location of placement depended on the characteristics of each accelerometer. In five studies the measurements by accelerometry were of 7 days and in the remaining three they were lower than this figure: more specifically, four [26], five [20] and six [29]. Participants wore accelerometers $24 \mathrm{~h}$ a day in four studies, during waking state hours in two $[23,26]$ and only during the school day in two others [20,29].

In three studies, the use of the accelerometer was accompanied by a logbook, which families and/or teachers had to fill out throughout the intervention in order to record the times at which children did not use the device [21,23,27]. Two other articles also used complementary instruments: a questionnaire to measure sedentary behaviour [21] and a questionnaire to measure time of exposure to screens [31]. 


\subsection{Subjective Measurement Instruments}

Subjective assessment methods were applied by a total of five studies, always using the questionnaire (Table 3). Only families were asked to complete the questionnaire in two studies [22,25], in two other studies the questionnaire was completed by both families and children with ASD $[27,28]$, and one study combined the participation of families and teachers [24].

All articles included issues related to the frequency and intensity of children's PA, using the MEND [22], PAQ-C [27], CHAMP [25] and GLTEQ adaptations [24,28]. For complementary instruments, two studies used a questionnaire to measure screen time $[25,28]$ and one incorporated a daily activity log to record children's type of play (individual or social) [24]. In addition, two articles used a checklist to record barriers in the practice of PA [24,25].

\section{Discussion}

The regular practice of PA plays a key role in the proper growth and development of all children, both physically and mentally. Its many benefits are especially significant in the ASD group, showing significant improvements in their difficulties. Therefore, by being aware of the influence of PA on children with ASD, its measurement (in terms of time and/or intensity) constitutes the first step to achieve a more active lifestyle, since only by identifying existing problems can measures and strategies be designed to promote greater PA practice. In this regard, this systematic review has aimed to identify and analyse the instruments used to assess the levels of PA (in terms of time and/or intensity) in Primary Education schoolchildren diagnosed with ASD.

The instruments used by the articles included in the review for assessing the PA among young people with ASD were divided into two main categories: objective and subjective. In the first one, used by a total of eight studies, the accelerometer stood out; while in the second group of studies (five), the questionnaire was the most demanded instrument.

\subsection{Accelerometer}

The accelerometer directly measures PA, its duration and intensity, and even the time children spent in sedentary behaviour. Moreover, they can be used in all activities and during sleep hours, water activities being an exception (in many cases).

Several models of accelerometers can be distinguished. In fact, in the eight articles of the review using the accelerometer, six different archetypes were found (GT1M, GT3X, GTX3+, Pro-3 SenseWear, Omron/HJA-750C and GT9X), among which one uniaxial and five triaxial accelerometers were identified. Despite the differences, the results of the instruments were similar, as they all recorded a low level of PA in participants with ASD. This finding is consistent with the study by Vanhelst et al. [32], who, when comparing the feasibility of a uniaxial (WG1M) and a triaxial (RT3) accelerometer to assess PA in a group of 13-16-year-old adolescents, concluded that the two types of accelerometers did not differ in the measurement of PA. However, other publications disagree, arguing that triaxial accelerometers provide more information and are more accurate when assessing PA and the energy expenditure of young people [33]. The placement of the device is a variable to be considered. Most of the studies analysed installed the device on the hips of participants, which coincides with most scientific research, as the hip has traditionally been the most common site of placement [34]. However, recent studies concluded that subject acceptance, especially for children, is higher when the accelerometer is placed on the wrist or ankle [35]. In fact, this is precisely where one of the main limitations of the accelerometer in young people with ASD lies: the ability of the subjects to withstand the device [36]. Nevertheless, according to the results described by the papers included in this systematic review, only one research student was excluded because he did not use the device long enough [31]. The remaining studies did not describe any difficulties with the use of the instrument by children with ASD. The good acceptance of the accelerometer by these children may have been influenced by some of the conditions of the studies, such as the low presence of participants with associated ID. Thus, it is considered difficult to generalise the usefulness 
of the instrument for the entire disorder, especially taking into consideration the findings of other interventions such as that of Oreskovic et al. [37], who found that the most common reason for abandonment in their study, among the 9 participants out of the initial 21, was the inability to tolerate the device due to the typical sensory problems of ASD.

These drawbacks are also compounded by the stereotypical (non-functional) movements associated with children with ASD, as the accelerometer may make it difficult to differentiate between voluntary and non-voluntary behaviours [21,31]. Furthermore, other publications have also pointed to the high cost of accelerometers as one of the main reasons for their occasional rejection [36], in favour of other cheaper and objective instruments (pedometers) or subjective tests such as self-report questionnaires [38].

As for the pedometer, no information is recorded about the frequency, duration and intensity of activity, so its use to assess young people's free participation in PA is limited [33]. PA bracelets also stand out as being easy to use, widely accepted by children and cheaper than accelerometers [39].

\subsection{Questionnaire}

The questionnaires used in the studies reviewed were mainly completed by families; while this does not eliminate the bias inherent to the subjectivity of these qualitative methods, it does mean that responses are not influenced by the usual planning and communication difficulties of children with ASD [7]. Indeed, other research argues that self-report questionnaires should not be used in childhood, especially before the age of 10, and that families and teachers should be responsible for carrying them out [38]. In terms of teacher participation, only one of the studies included in this review involved teachers [24], which is essential to implement PA in schools.

According to another study [40], PA questionnaires should ask participants for information about the PA carried out during the week and during the weekend, in order to be able to assess the total amount of PA. In the study by Bricout et al. [27], the PAQ-C was used, including questions aimed at identifying PA performed during weekdays and weekends. This questionnaire showed a moderate-high reliability with respect to PA quantified through accelerometry, good internal consistency and reliability over 4 months of intervention [41]. However, the GLTEQ questionnaire used by two of the studies included in the review [24,28] was called into question by the analysis of Cancela-Carral et al. [40], whose results showed a low degree of correlation with objective measures. There are many other questionnaires which, although not validated in children with ASD, are suitable for the assessment of PA in childhood and adolescence [39]. Therefore, due to the characteristics of children with ASD, their reliability should be assessed in this population.

The subjective nature of the questionnaire, as opposed to the objective nature of the accelerometer, is the main drawback of this evaluation method since, as all the interventions analysed show, the difficulty to accurately remember the different activities carried out in a certain period of time is a major limitation when it comes to notifying the safety of the instrument. Other studies which have investigated the reliability and validity of PA questionnaires in children have highlighted this limitation [38,42], ranking it as the greatest barrier when using the questionnaire. However, this method of measurement has notable advantages which render it the most commonly used resource [40], highlighting its low economic cost [38], ease of administration, capacity for simultaneous evaluation in large samples [40] and the possibility of learning about the context and type of activity [42].

\subsection{Physical Activity Levels}

Regarding PA levels, all instruments, objective and subjective, detected a low level of PA in children with ASD; they did not comply with the recommendations of 60 min of daily moderate-to-high intensity PA and were physically less active than their normotypically developing peers. Some studies included in the review argued that girls participated in less PA than boys $[21,24,28]$ and that as the age of the participants increased, PA practice decreased [20,21,24]. Additionally, it should be noted that the study by Memari et al. [24] 
reported a clear preference of participants with ASD for solitary play, which is supported by the results of Healy et al. [28], who reported that children with the disorder participate in fewer sports than their peers without ASD. Must et al. [25], on the other hand, detected more barriers towards the PA practice in students with ASD than in schoolchildren with normotypical development.

\subsection{Study Limitations}

This systematic review was subjected to a number of limitations. Firstly, it should be mentioned that the studies were only searched in the databases mentioned, and relevant information may have remained unanalysed. In addition, a filter was established by language, selecting only those publications in Spanish or English, and therefore, documents written in other languages, although they may be of interest, were excluded. It is necessary to point out that the systematic review conducted is of a qualitative nature; in other words, it is a review without meta-analysis and, consequently, the evidence has been presented in a descriptive manner and without statistical analysis. Moreover, the methodological quality of the studies/risk of bias was not evaluated. Finally, although the main objective of this systematic review was to analyse both the objective and subjective instruments used to assess the levels of PA in primary schoolchildren diagnosed with ASD, the possible effect associated to comorbities, which might influence the results of the tests, have not been analysed.

\section{Conclusions}

The accelerometer and the questionnaire were the instruments mainly chosen to measure the PA level (in terms of time and/or intensity) in children with ASD. Different models have been used in both instruments, but all of them, besides showing very similar results in terms of PA practice, have detected the same or similar drawbacks. In the case of the accelerometer, they highlighted the inability of the instrument to evaluate water activities and its difficulty to discern the functional movements from the stereotypical ones characteristic of ASD. The questionnaires, on the other hand, were qualified as useful instruments, but they were conditioned by the participants' personal interpretation. As for the questionnaires, validity and reliability studies of these instruments should be carried out in populations with ASD.

The low levels of PA in the ASD group indicate the need for further research in this field, as well as the need to encourage PA practice through the promotion of sports programmes designed to meet the needs of children with the disorder. Especially the school environment, as it is one of the places where young people spend more time, should guarantee, by introducing the appropriate measures and adaptations, that all students understand PA as a means to favour personal and social development.

Author Contributions: Conceptualisation, P.L.-V. and J.R.-D.; methodology, J.R.-D. and S.L.-G.; M.B.-F., M.M.-G. and S.L.-G.; investigation, J.R.-D., J.L.M. and S.L.-G.; data curation, P.L.-V. and J.R.-D.; writing-original draft preparation, P.L.-V. and J.R.-D.; writing—review and editing, M.B.-F., M.M.-G., J.L.M. and S.L.-G.; supervision, J.R.-D. and S.L.-G. All authors have read and agreed to the published version of the manuscript.

Funding: This research received no external funding.

Institutional Review Board Statement: Not applicable.

Informed Consent Statement: Not applicable.

Data Availability Statement: Data is contained within article.

Conflicts of Interest: The authors declare no conflict of interest. 


\section{References}

1. Rissardi, G.G.; Cipullo, J.P.; Moreira, G.; Ciorlia, L.A.; Cesarino, C.; Giollo-Junior, L.T.; Zanesco, A.; Vilela-Martin, J.F. Prevalence of Physical Inactivity and its effects on blood pressure and metabolic parameters in a Brazilian urban population. Int. J. Cardiovasc. Sci. 2018, 31, 594-602. [CrossRef]

2. World Health Organization. Physical Activity. Available online: https://www.who.int/es/news-room/fact-sheets/detail/ physical-activity (accessed on 2 April 2020).

3. Gaetano, A. Relationship between physical inactivity and effects on individual health status. J. Phys. Educ. Sport. 2016, 16, 1069-1074. [CrossRef]

4. González, K.; Fuentes, J.; Márquez, J.L. Physical inactivity, sedentary behavior and chronic diseases. Korean J. Fam. Med. 2017, 38, 111-115. [CrossRef] [PubMed]

5. World Health Organization. Obesity and Overweight. Available online: https://www.who.int/news-room/fact-sheets/detail/ obesity-and-overweight (accessed on 2 April 2020).

6. Jones, R.A.; Downing, K.; Rinehart, N.J.; Barnett, L.M.; May, T.; McGillivray, J.A.; Hinkley, T. Physical activity, sedentary behavior and their correlates in children with autism spectrum disorder: A systematic review. PLoS ONE 2017, 12, e0172482. [CrossRef]

7. American Psychiatric Association. Manual Diagnóstico y Estadístico de los Trastornos Mentales (DSM-V), 5th ed.; Editorial Médica Panamericana: Madrid, Spain, 2014.

8. Baio, J.; Wiggins, L.; Christensen, D.L.; Menner, M.J.; Daniels, J.; Warren, Z.; Dowling, N.F. Prevalence of autism spectrum disorder among children aged 8 years- Autism and developmental disabilities monitoring network, 11 sites, United States, 2014. MMWR. Surveill. Summ. 2018, 67, 1-23. [CrossRef] [PubMed]

9. Srinivasan, S.M.; Pescatello, L.S.; Bhat, A.N. Current perspectives on physical activity and exercise recommendations for children and adolescents with autism spectrum disorders. Phys. Ther. 2014, 94, 875-889. [CrossRef] [PubMed]

10. Yu, C.; Wong, S.; Lo, F.; So, R.; Chan, D. Study protocol: A randomized controlled trial study on the effect of a game-based exercise training program on promoting physical fitness and mental health in children with autism spectrum disorder. $B M C$ Psychiatry 2018, 18, 56-65. [CrossRef]

11. Hill, A.P.; Zuckerman, K.E.; Fombonne, E. Obesity and Autism. Pediatrics 2015, 136, 1051-1061. [CrossRef]

12. Golden, D.; Getchell, N. Physical activity levels in children with and without autism spectrum disorder when playing active and sedentary Xbox Kinect videogames. Games Health J. 2017, 6, 97-103. [CrossRef]

13. Memari, A.H.; Mirfazeli, F.S.; Kordi, R.; Shayestehfar, M.; Moshayedi, P.; Mansournia, M.A. Cognitive and social functioning are connected to physical activity behavior in children with autism spectrum disorder. Res. Autism Spectr. Disord. 2017, $33,21-28$. [CrossRef]

14. Nalbant, S. Effects of participation in inclusive physical activity on social skills of individuals with autism spectrum disorder. J. Educ. Train Stud. 2018, 6, 255-261. [CrossRef]

15. Liu, T.; Fedak, A.T.; Hamilton, M. Effect of physical activity on the stereotypic behaviors of children with autism spectrum disorder. Int. J. Sch. Health. 2016, 3, 17-22. [CrossRef]

16. Bo, J.; Pang, Y.; Dong, L.; Xing, Y.; Xiang, Y.; Zhang, M.; Wright, M.; Shen, B. Brief report: Does social functioning moderate the motor outcomes of a physical activity program for children with autism spectrum disorders-A pilot study. J. Autism Dev. Disord. 2019, 49, 415-421. [CrossRef] [PubMed]

17. Pan, C.Y.; Chu, C.H.; Tsai, C.L.; Sung, M.C.; Huang, C.Y.; Ma, W.Y. The impacts of physical activity intervention on physical and cognitive outcomes in children with autism spectrum disorder. Autism 2016, 21, 190-202. [CrossRef]

18. Godard, C.; Carlín, L.; Torres, J.; Rodríguez, M.P.; Leyton, B.; Salazar, G. Nivel de intensidad de las principales actividades físicas de escolares chilenos: Determinación por acelerometría. Rev. Chil. Nut. 2016, 43, 247-254. [CrossRef]

19. Liberati, A.; Altman, D.G.; Tetzlaff, J.; Mulrow, C.; Gøtzsche, P.C.; Ioannidis, F.P.; Moher, D. The PRISMA statement for reporting systematic reviews and meta-analyses of studies that evaluate health care interventions: Explanation and elaboration. PLoS Med. 2009, 6, e1000100. [CrossRef]

20. Pan, C.Y. Objectively measured physical activity between children with Autism Spectrum Disorders and children without disabilities during inclusive recess setting in Taiwan. J. Autism Dev. Disord. 2008, 38, 1292-1301. [CrossRef]

21. Memari, A.H.; Ghaheri, B.; Ziaee, V.; Kordi, R.; Hafizi, S.; Moshayedi, P. Physical activity in children and adolescents with autism assessed by triaxial accelerometry. Pediatric Obes. 2012, 8, 150-158. [CrossRef]

22. Hinckson, E.A.; Dickinson, A.M.; Water, T.; Sands, M.; Penman, L. Physical activity, dietary habits and overall health in overweight and obese children and youth with intellectual disability or autism. Res. Dev. Disabil. 2013, 34, 1170-1178. [CrossRef]

23. Tyler, K.; MacDonald, M.; Menear, K. Physical activity and physical fitness of school-aged children and youth with autism spectrum disorders. Autism Res. Treat. 2014, 2014, 312163. [CrossRef]

24. Memari, A.H.; Panahi, N.; Ranjbar, N.; Moshayedi, P.; Shafiei, M.; Kordi, R.; Ziaee, V. Children with autism spectrum disorder and patterns of participation in daily physical and play activities. Neurol. Res. Int. 2015, 531906. [CrossRef] [PubMed]

25. Must, A.; Phillips, S.M.; Carol, C.; Bandini, L.G. Barriers to physical activity in children with autism spectrum disorders: Relationship to physical activity and screen time. J. Phys. Act. Health 2015, 12, 529-534. [CrossRef]

26. Haegele, J.A.; Zhu, X.; Kirk, T.N. Weekday physical activity and health-related fitness of youths with Visual Impairments and those with Autism Spectrum Disorder and Visual Impairments. J. Vis. Impair. Blind. 2018, 112, 372-384. [CrossRef] 
27. Bricout, V.A.; Pace, M.; Dumortier, L.; Baillieul, F.; Favre-Juvin, A.; Guinot, M. Reduced cardiorespiratory capacity in children with Autism Spectrum Disorders. J. Clin. Med. 2018, 7, 361. [CrossRef] [PubMed]

28. Healy, S.; García, J.M. Psychosocial correlates of physical activity participation and screen-time in typically developing children and children on the autism spectrum. J. Dev. Phys. Disabil. 2018, 31, 313-328. [CrossRef]

29. Woodman, A.C.; Breviglia, E.; Mori, Y.; Golden, R.; Maina, J.; Wisniewski, H. The effect of music on exercise intensity among children with Autism Spectrum Disorder: A pilot study. J. Clin. Med. 2018, 7, 38. [CrossRef]

30. Garcia, J.M.; Leahy, N.; Rivera, P.; Renziehausen, J.; Samuels, J.; Fukuda, D.H.; Stout, J.R. Brief report: Preliminary efficacy of a judo program to promote participation in physical activity in youth with Autism Spectrum Disorder. J. Autism. Dev. Disord. 2019, 50, 1418-1424. [CrossRef]

31. Garcia, J.M.; Leahy, N.; Rivera, P.; Brazendale, K.; Rice, D.J. The association among demographic factors, health behaviors and sleep quality in youth with Autism Spectrum Disorder. Disabil. Health J. 2019, 13, 100885. [CrossRef]

32. Vanhelst, J.; Béghin, L.; Duhamel, A.; Bergman, P.; Sjöström, M.; Gottrand, F. Comparison of uniaxial and triaxial accelerometry in the assessment of physical activity among adolescents under free-living conditions: The HELENA study. BMC Med. Res. Metodol. 2012, 12, 26. [CrossRef]

33. Plasqui, G.; Westerterp, K.R. Physical activity assessment with accelerometers: An evaluation against doubly labeled water. Obesity 2007, 15, 2371-2379. [CrossRef]

34. Montoye, A.H.; Moore, R.W.; Bowles, H.R.; Horycinski, R.; Pfeiffer, K.A. Reporting accelerometer methods in physical intervention studies: A systematic review and recommendations for authors. Br. J. Sports Med. 2018, 52, 1507-1516. [CrossRef] [PubMed]

35. Duncan, M.J.; Roscoe, C.M.; Faghy, M.; Tallis, J.; Eyre, E.L. Estimating physical activity in children aged 8-11 years using accelerometry: Contributions from fundamental movement skills and different accelerometer placements. Front. Physiol. 2019, 10, 242. [CrossRef] [PubMed]

36. Hauck, J.L.; Ketcheson, L.R.; Ulrich, D.A. Methodology to promote physical activity monitoring adherence in youth with Autism Spectrum Disorder. Front. Public Health 2016, 4, 206. [CrossRef]

37. Oreskovic, N.M.; Neumeyer, A.M.; Duggan, M.P.; Kuhlthau, K.A. Assessment of walking routes as a possible approach for promoting physical activity in children with Autism Spectrum Disorder: Brief Report. Dev. Neurorehabilit. 2019, 23 , 59-63. [CrossRef] [PubMed]

38. Bender, J.M.; Brownson, R.C.; Elliott, M.B.; Haire-Joshu, D.L. Children's physical activity: Using accelerometers to validate a parent proxy record. Med. Sci. Sports Exerc. 2005, 37, 1409-1413. [CrossRef] [PubMed]

39. Jurado-Castro, J.M.; Llorente-Cantarero, F.J.; Gil-Campos, M. Evaluación de la actividad física en niños. Acta Pediatrica Esp. 2019, 77, 94-99.

40. Cancela-Carral, J.M.; Lago-Ballesteros, J.; Ayán-Pérez, C.; Mosquera-Morono, M.B. Análisis de fiabilidad y validez de tres cuestionarios de autoinforme para valorar la actividad física realizada por adolescentes españoles. Gac. Sanit. 2016, 30, 333-338. [CrossRef]

41. Voss, C.; Dean, P.H.; Gardner, R.F.; Duncombe, S.L.; Harris, K.C. Validity and reliability of the physical activity questionnaire for children (PAQ-C) and adolescents (PAQ-A) in individuals with congenital heart disease. PLoS ONE 2017, 12, e0175806. [CrossRef]

42. Hidding, L.M.; Chinapaw, M.J.; Van Poppel, M.N.; Mokkink, L.B.; Altenburg, T.M. An updated systematic review of childhood physical activity questionnaires. Sports Med. 2018, 48, 2797-2842. [CrossRef] 